\title{
HUMIFIED FRACTION OF ORGANIC MATTER DUE TO PLANT MIXTURE CULTIVATION ${ }^{1}$
}

\author{
TONY JARBAS FERREIRA CUNHA ${ }^{2}$, VANDERLISE GIONGO ${ }^{2 *}$, ALESSANDRA MONTEIRO SALVIANO², \\ FLÁVIO ADRIANO MARQUES ${ }^{3}$, LUCIANO PASQUALOTO CANELLAS ${ }^{4}$
}

\begin{abstract}
The aim of this study was to assess the organic matter changes in quantity and quality, particularly of the humic fraction in the surface layer $(0-20 \mathrm{~cm})$, of a Typic Plinthustalf soil under different management of plant mixtures used as green manure for mango (Mangifera indica L.) crops. The plant mixtures, which were seeded between rows of mango trees, were formed by two groups of leguminous and non -leguminous plants. Prior to sowing, seeds were combined in different proportions and compositions constituting the following treatments: 100\% non-leguminous species (NL); 100\% leguminous species (L); 75\% $\mathrm{L}$ and $25 \% \mathrm{NL} ; 50 \% \mathrm{~L}$ and $50 \% \mathrm{NL} ; 25 \% \mathrm{~L}$ and $75 \% \mathrm{NL}$; and $100 \%$ spontaneous vegetation, considered a control. The plant mixtures that grew between rows of mango trees caused changes in the chemical composition of the soil organic matter, especially for the treatments $50 \% \mathrm{~L}$ and $50 \% \mathrm{NL}$ and $25 \% \mathrm{~L}$ and $75 \%$ NL, which increased the content of humic substances in the soil organic matter. However, the treatment $25 \% \mathrm{~L}$ and $75 \%$ NL was best at minimising loss of total organic carbon from the soil. The humic acids studied have mostly aliphatic characteristics, showing large amounts of carboxylic and nitrogen groups and indicating that most of the organic carbon was formed by humic substances, with fulvic acid dominating among the alkali soluble fractions.
\end{abstract}

Keywords: Humic substances. Infrared spectroscopy. Mangifera indica. Soil quality. Soil management.

\section{FRAÇÕES HUMIFICADAS DA MATÉRIA ORGÂNICA EM FUNÇÃO DO CULTIVO DE COQUETÉIS VEGETAIS}

RESUMO - O objetivo desse trabalho foi avaliar as mudanças na quantidade e qualidade da matéria orgânica, particularmente da fração húmica, na camada superficial $(0-20 \mathrm{~cm})$ de um Argissolo Vermelho-Amarelo sob diferentes coquetéis vegetais usados como adubação verde da cultura da mangueira (Mangifera indica L.). Os coquetéis vegetais, semeados nas entrelinhas das mangueiras, foram formados por dois grupos de espécies leguminosas e não-leguminosas. As sementes, antes da semeadura, foram combinadas em diferentes composições e proporções que constituíram os tratamentos: 100\% de espécies não-leguminosas (NL); 100\% de espécies leguminosas (L); $75 \%$ L e $25 \%$ NL; $50 \%$ L e $50 \%$ NL; $25 \%$ L e $75 \%$ NL; e $100 \%$ vegetação espontânea, considerado como testemunha. Constatou-se que a aplicação de coquetéis vegetais na entrelinha da cultura da mangueira promoveu alterações na composição química da matéria orgânica do solo, com destaque para os tratamentos $50 \%$ L e $50 \%$ NL e $25 \%$ L e $75 \%$ NL que aumentaram o conteúdo de substâncias húmicas na matéria orgânica do solo. Não obstante, o tratamento $25 \%$ L e $75 \%$ NL foi o indicado para minimizar as perdas de carbono orgânico total do solo. Os ácidos húmicos estudados são de característica mais alifática apresentando grande quantidade de grupos carboxílicos e nitrogenados e sendo a maior parte do carbono orgânico do solo constituído por substâncias húmicas, tendo a fração ácidos fúlvicos como dominante entre as frações alcalino solúveis.

Palavras-chaves: Espectroscopia de infravermelho. Manejo do solo. Mangifera indica. Qualidade do solo. Substâncias húmicas.

\footnotetext{
*Corresponding author

${ }^{1}$ Received for publication in 08/14/2014; accepted in.04/18/2016.

${ }^{2}$ Empresa Brasileira de Pesquisa Agropecuária, Petrolina, PE, Brazil; tony.cunha@embrapa.br, vanderlise.giongo@embrapa.br, alessandra.salviano@embrapa.br.

${ }^{3}$ Empresa Brasileira de Pesquisa Agropecuária, Recife, PE, Brazil; flavio.marques@embrapa.br.

${ }^{4}$ Biological Inputs to Agriculture Development Center, Universidade Estadual do Norte Fluminense Darcy Ribeiro, Campos dos Goytacazes, RJ, Brazil; canellas@uenf.br.
} 


\section{INTRODUCTION}

The total organic carbon content (TOC) is usually low in tropical soils of semiarid regions, often not exceeding $10 \mathrm{~g} \mathrm{~kg}^{-1}$ soil mass (SALCEDO; SAMPAIO, 2008). In addition, irrigated crops in the Brazilian semiarid region can accelerate the decomposition of organic matter (OM) and may change the quality and quantity of the humified fractions of soil OM (CUNHA et al., 2009a). Carbon (C) is the main component of OM, affecting important physical, chemical and biological soil processes (BRANCALIÃO; MORAES, 2008). Briefly, OM can be defined as a heterogeneous mixture of organic molecules arising from the transformation, in varying degrees, of biopolymers (carbohydrates, lignins, proteins and fatty acids) from plants, animals and microorganisms (SIMPSON, 2002). The humic fractions form an essential part of OM and are operationally defined on the basis of solubility in aqueous alkalis or acids. Since the majority of OM is formed by the humified fraction, its association with soil fertility (KONONOVA, 1982) and its use as an indicator of soil quality (ORLOV, 1998) are common. The humification process or humic substance (HS) formation could occur in nature by the progressive accumulation of more hydrophobic and recalcitrant molecules in the soil (PICCOLO, 2012). Therefore, the relationships of humic acid (HA)/fulvic acid (FA) and humin (H)/TOC can express the relative degree of humification of the OM of soil and its lability.

The elemental analysis of humified soil matter can be obtained from the quantification of $\mathrm{C}$ and nitrogen $(\mathrm{N})$ contained in different humic fractions (HA, FA and $\mathrm{H}$ ), achieved using spectroscopic methods, especially with employment of ${ }^{13} \mathrm{C}$ nuclear magnetic resonance $\left({ }^{13} \mathrm{C} \mathrm{NMR}\right)$. The application of spectroscopy in the infrared region using diffuse reflectance infrared Fourier transform (DRIFT) on soil samples is comparatively cheaper than ${ }^{13} \mathrm{C} \mathrm{NMR}$, easy to prepare and fast performing (a few minutes per sample) (LIEFELD, 2006; FRANCIOSO et al., 2009; CARLETTI et al., 2010; FERRARI et al., 2011; SIMONETTI et al., 2012), including the assessment of resulting changes from management.

The use of plant mixtures in irrigated systems can lead to changes in the properties of HSs in the soil as possible changes in their spectroscopic characteristics. Fourier transform infrared spectroscopy is a useful method for the characterization of OM (OLK et al., 2000; VAZ Jr. et al., 2015) and HSs (MAO et al., 2008; CUNHA et al., 2009a, b; FRANCIOSO et al., 2009). This technique provides detailed information about the oxygen-containing groups present in complex molecules, since polar groups usually show intense infrared signals. An important information that can be obtained from the infrared spectrum is hydrophobicity index, since expresses the relationship between unpolar $(-\mathrm{CH} 3)$ and polar groups (-OH, C-O) (FREIXO et al., 2002).

In the São Francisco valley, green manure consisting of a combination of different species of leguminous and non-leguminous plants, commonly called 'plant mixtures', has aroused farmers interested in irrigated agriculture. At the same time, few changes are known in the quantity and quality of soil OM resulting from continued use of this practice. Due to their larger $\mathrm{C} / \mathrm{N}$ ratio and therefore slower rate of decomposition, it is expected that plant mixtures composed of higher proportions of non-leguminous species (grasses and oilseeds) promote increased $\mathrm{C}$ content in the soil and greater stability in the soil system, thus favouring the process of humification. Mango trees are a crop of great economic importance to the region; mango crops have a long cultivation cycle, with the presence of severe humified OM for increasing nutrient availability, not due to the decomposition and slower mineralization of nutrients. In addition, soil OM fractions are sensitive to land use change and are related to several soil properties. There is no information regarding changes in the quantity and quality of HSs caused by use of plant mixture applications, thus justifying its study. The objective of this work was to evaluate the changes in quantity and quality of OM of HSs of a Typic Plinthustalf soil under different plant mixtures used as green manure between rows of mango trees.

\section{MATERIAL AND METHODS}

The experiment was conducted at the Bebedouro Experimental Field, from the Embrapa semiarid, Petrolina-PE $\left(09^{\circ} 09^{\prime} \mathrm{S}, 42^{\circ} 22^{\prime} \mathrm{W}\right)$ on a Typic Plinthustalf, medium-texture soil (USDA, 2010). The climate is of BSwh' type according to the Köppen classification, with average annual rainfall of $570 \mathrm{~mm}$ and monthly average temperatures ranging from $24.2-28.1{ }^{\circ} \mathrm{C}$. Physical and chemical analysis results of soil characterisation following the Classen (1997) methods showed that the layer of 0 $20 \mathrm{~cm}$ had the following characteristics: 900, 10 and $90 \mathrm{~g} \mathrm{~kg}^{-1}$ of sand, silt and clay, respectively; low TOC content $\left(4.1 \mathrm{~g} \mathrm{~kg}^{-1}\right)$; moderate acidity $(\mathrm{pH}=$ $6.0)$; low electrical conductivity $\left(0.10 \mathrm{dS} \mathrm{m}^{-1}\right)$; high levels of phosphorus $\left(25 \mathrm{mg} \mathrm{\textrm {dm } ^ { - 3 }}\right)$ and potassium $\left(0.30 \mathrm{cmol}_{\mathrm{c}} \mathrm{dm}^{-3}\right)$; low levels of calcium, magnesium, sodium and aluminium (1.0, 0.5, 0.01 and $0.05 \mathrm{cmol}_{\mathrm{c}} \mathrm{dm}^{-3}$, respectively); low acidity potential $\left(0.66 \mathrm{cmol}_{\mathrm{c}} \mathrm{dm}^{-3}\right)$; and consequently, low base sums and cation exchange capacity (1.81 and $2.47 \mathrm{cmol}_{\mathrm{c}} \mathrm{dm}^{-3}$, respectively). The mango seedlings with $80-90 \mathrm{~cm}$ were implemented in 2005 in the spacing of $6 \times 8 \mathrm{~m}$. Fertiliser was applied to each planting hole of mango seedlings of the Tomy 
cultivar: $59 \mathrm{~g} \mathrm{P}_{2} \mathrm{O}_{5}, 20 \mathrm{~g} \mathrm{~K} \mathrm{O}_{2}, 59 \mathrm{~g} \mathrm{Ca}$ and $40 \mathrm{~g} \mathrm{~S}$, using simple superphosphate and potassium chloride as nutrients sources, were applied.

The treatments seeded between rows were formed by two species groups, in different proportion: i) leguminous - Calopogonium mucunoides, Crotalaria juncea, Crotalaria spectabilis, Canavalia ensiformis, Cajanus cajan L. and Dolichos lablab L.; ii) non-leguminous plants Sesamum indicum L., Chrysanthemum peruviamum, Ricinus communis L., Pennisetum americanum L. and Sorghum vulgare Pers.

The seeds species were combined and mixed in different proportions and compositions prior to sowing that constituted the following treatments used: T1 $-100 \%$ of non-leguminous species (NL); $\mathrm{T} 2-100 \%$ of leguminous species (L); T3 $-75 \% \mathrm{~L}$ and $25 \% \mathrm{NL}$; T4 $-50 \% \mathrm{~L}$ and $50 \% \mathrm{NL}$; T5 - 25\% L and $75 \% \mathrm{NL}$; and $\mathrm{T} 6-100 \%$ spontaneous vegetation (SV), which was considered a control treatment, composed of Commelina benghalensis L.,
Macroptilium atropurpureum Urb., Desmodium tortuosum (Sw.) DC. and Acanthospermum hispidum DC. The experimental design was a randomised block with four replications.

The species were seeded during the rainy season between the mango rows for 3 years beginning 2006 at a distance of $2.0 \mathrm{~m}$ from the plant stems in furrows at a spacing of $0.5 \mathrm{~m}$; each parcel corresponds to an area of $160 \mathrm{~m}^{2}(16 \times 10 \mathrm{~m})$ containing two mango plants. The mango tree sowing was carried out between rows within each parcel. To ensure uniform seed distribution in rows, seeds smaller in size/weight (10-70 g 1,000 seeds $\left.{ }^{-1}\right)$ were initially distributed, followed by intermediatesized ones $\left(200-300\right.$ g 1,000 seeds $\left.{ }^{-1}\right)$ and, subsequently, larger $\left(850-1,450 \mathrm{~g} 1,000\right.$ seeds $\left.^{-1}\right)$ ones, thus avoiding any segregation effect. The seed quantities used in each treatment are presented in Table 1. An experimental design of entirely randomised blocks with four replications was used.

Table 1. Seed mass (g) of leguminous species (L) and non-leguminous species (NL) planted per treatment.

\begin{tabular}{|c|c|c|c|c|c|c|}
\hline \multirow[t]{3}{*}{ Species } & \multirow[b]{2}{*}{$100 \% \mathrm{NL}$} & \multicolumn{5}{|c|}{ Treatments } \\
\hline & & $100 \% \mathrm{~L}$ & $\begin{array}{c}75 \% \mathrm{~L} \text { and } \\
25 \% \mathrm{NL}\end{array}$ & $\begin{array}{c}50 \% \mathrm{~L} \text { and } \\
50 \% \mathrm{NL}\end{array}$ & $\begin{array}{c}25 \% \mathrm{~L} \text { and } \\
75 \% \mathrm{NL}\end{array}$ & SV \\
\hline & & \multicolumn{5}{|c|}{ Leguminous } \\
\hline Calopogonium mucunoides & 0.0 & 82.0 & 61.5 & 41.0 & 20.5 & 0.0 \\
\hline Crotalaria juncea & 0.0 & 260.0 & 195.0 & 130.0 & 65.0 & 0.0 \\
\hline Crotalaria spectabilis & 0.0 & 382.0 & 286.5 & 191.0 & 95.5 & 0.0 \\
\hline Canavalia ensiformis & 0.0 & $4,786.0$ & $3,589.5$ & $2,393.0$ & $1,196.5$ & 0.0 \\
\hline Cajanus cajan & 0.0 & 272.0 & 204.0 & 136.0 & 68.0 & 0.0 \\
\hline \multirow[t]{2}{*}{ Dolichos lablab } & 0.0 & $1,280.0$ & 980.0 & 640.0 & 320.0 & 0.0 \\
\hline & \multicolumn{6}{|c|}{ Non-leguminous } \\
\hline Sesamum indicum & 64.0 & 0.0 & 16.0 & 32.0 & 48.0 & 0.0 \\
\hline Chrysanthemum peruviamum & 200.0 & 0.0 & 50.0 & 100.0 & 150.0 & 0.0 \\
\hline Ricinus communis & $2,210.0$ & 0.0 & 552.5 & $1,105.0$ & $1,657.5$ & 0.0 \\
\hline Pennisetum americanum & 64.0 & 0.0 & 16.0 & 32.0 & 48.0 & 0.0 \\
\hline Sorghum vulgare & 160.0 & 0.0 & 40.0 & 80.0 & 120.0 & 0.0 \\
\hline
\end{tabular}

$\mathrm{SV}$ - spontaneous vegetation.

For 3 years, the plant mixtures were cultivated during the rainy season; seeds that make up each plant mixture were sown between rows of mango trees. At the time of flowering, the green manure plants were mowed close to the ground $(1 \mathrm{~cm})$, and samples containing parts of plants (stalks and leaves) were collected. After plant mixtures were mowed, phytomass was deposited in the canopy projection of the mango trees. In Table 2 , the amount of phytomass produced and nutrients in the different treatments, as Silva (1999) analysed, can be observed.

Four soil samples were collected, each consisting of a composed sample, in the crop line of mango trees in 2009, after 3 years of plant mixture cultivation at a depth of $0-20 \mathrm{~cm}$.

Table 2. Dry matter; accumulated nutrients; and $\mathrm{C} / \mathrm{N}, \mathrm{C} / \mathrm{P}$ and N/P ratios of the shoots of the plant mixtures (average of three cycles).

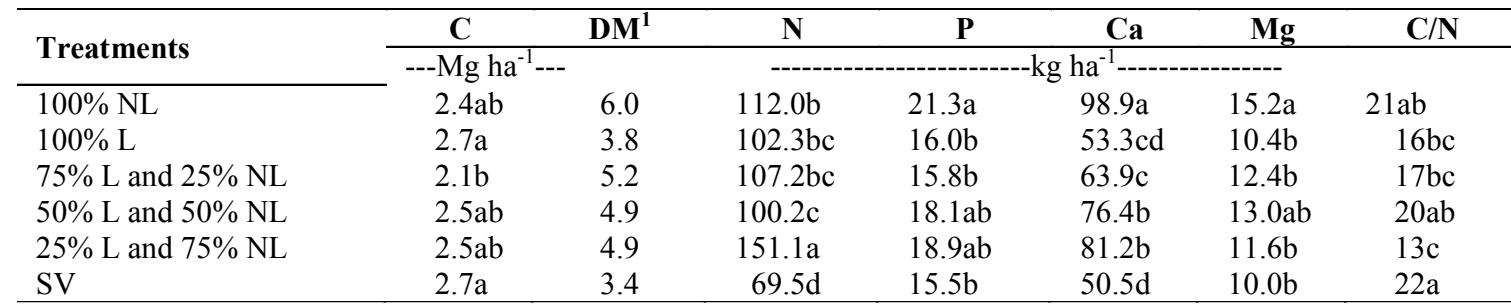

Means followed by the same letter in the column do not differ by Tukey test at level of $5 \%$ probability. DM - dry matter, $\mathrm{NL}$ - non-leguminous species, $\mathrm{L}$ - leguminous species, $\mathrm{SV}$ - spontaneous vegetation. 


\section{Humic substance quantification}

The quantitative chemical fractionation of HSs of the soil was performed according to methods of Benites et al. (2003) to obtain H, HA and FA. The quantitative determination of organic $\mathrm{C}$ in each fraction was performed by wet combustion with potassium dichromate (YEOMANS; BREMNER, 1988) and the values expressed as percentages of TOC. The relations $\mathrm{C}_{\mathrm{HA}} / \mathrm{C}_{\mathrm{FA}}, \mathrm{C}_{\mathrm{H}} /\left(\mathrm{C}_{\mathrm{FA}}+\mathrm{C}_{\mathrm{HA}}\right), \mathrm{C}_{\mathrm{H}}+$ $\mathrm{C}_{\mathrm{FA}}+\mathrm{C}_{\mathrm{HA}} / \mathrm{TOC}$ and $\mathrm{C}_{\mathrm{H}}+\mathrm{C}_{\mathrm{FA}}+\mathrm{C}_{\mathrm{HA}}$ were used to interpret the obtained data, according to methods of Labrador Moreno (1996) and Benites (2002).

\section{Extraction and humic acid purification}

The OM extraction and fractionation to obtain $\mathrm{HA}$ and its purification were performed according to the International Humic Substances Society method, whose protocol is described by Swift (1996), with the following modifications: pre-treatment of soil samples was made with hydrochloric acid $(\mathrm{HCl})$ to a solution $\mathrm{pH}$ between 1 and 2 for reducing ash content (metal removal adsorbed), and suspended solids removal was performed using $\mathrm{K}^{+}$ (NOVOTNY, 2002), as briefly described next. After soil pre-treatment with $0.1 \mathrm{M} \mathrm{HCl}$, sample amounts with around $1,000 \mathrm{mg}$ of HA (as estimated by quantitative fractionation) and up to $200 \mathrm{~mL}$ of 0.1 $M$ sodium hydroxide under inert atmospheric dinitrogen $\left(\mathrm{N}_{2}\right)$ were added. After shaking for $24 \mathrm{~h}$, the material was centrifuged at $10,000 \mathrm{~g}$ for $30 \mathrm{~min}$. The supernatant (alkaline extract) was collected and the $\mathrm{pH}$ immediately adjusted to 2.0 by dripping of an aqueous solution of $20 \% \mathrm{HCl}$. The residue was subjected to extraction again, and the supernatant was joined to the previous setting, with the $\mathrm{pH}$ immediately brought to 2.0 . The acidified extract was reserved for the HA precipitation. After $18 \mathrm{~h}$, the excess supernatant (FA) was siphoned and discarded. The remaining material was centrifuged at 5,000 $\mathrm{g}$ for $10 \mathrm{~min}$, after which the supernatant (FA) was removed. For removal of soluble solids in suspension, HA was re-dissolved in a potassium hydroxide solution to $0.1 \mathrm{M}$, after which potassium chloride $(\mathrm{KCl})$ was added to achieve a concentration of $0.3 \mathrm{M} \mathrm{K}^{+}$and then centrifuged at $4,000 \mathrm{~g}$ for 15 min. After this step, the HA was purified with a $0.5 \%$ hydrogen fluoride $+\mathrm{HCl}$ (SCHNITZER, 1982) solution for $24 \mathrm{~h}$ and centrifuged at $5,000 \mathrm{~g}$. The process was repeated two additional times. The purified samples were washed with deionised water and transferred into cellophane bags of approximately $100 \mathrm{~mL}$. Dialysis samples were evaluated in deionised water in a $20-\mathrm{L}$ container (12 bags per battery). The water was replenished twice daily until there was no further increase in microsiemens to measure the electrical conductivity of the dialysis water after $1 \mathrm{~h}$ of this exchange. The samples were then frozen, lyophilised and placed in a desiccator.

To measure DRIFT, the HA was mixed in potassium bromide $(1: 100, \mathrm{w} / \mathrm{w})$ and compressed into tablet form. Spectra were obtained from 100 scans in the range of $400-4,000 \mathrm{~cm}^{-1}$ with a spectral resolution of $2 \mathrm{~cm}^{-1}$ using Shimadzu Prestige 21 equipment. Absorption bands in the regions of 2,928 $\mathrm{cm}^{-1}$ and $1,050-1,080 \mathrm{~cm}^{-1}$ denominate in this the work hydrophobicity index (HI), since they express the relationship between nonpolar methyl $\left(-\mathrm{CH}_{3}\right)$ and polar $(-\mathrm{OH}, \mathrm{C}-\mathrm{O})$ groups, according Freixo et al. (2002). The average results were compared using the Tukey test at the $5 \%$ level of probability.

\section{RESULTS AND DISCUSSION}

\section{Humic substance quantification}

The plant mixtures used between rows in the mango cultivation induced a reduction in TOC in all treatments compared to the control (SV), with the exception of the $75 \% \mathrm{~L}$ and $25 \% \mathrm{NL}$ treatment (Table 3). This decrease was in the order of $7-28 \%$ of the composition according to the plant mixtures. The greatest decreases were observed in treatments formed only by non-leguminous ( $100 \% \mathrm{NL})$ or only leguminous $(100 \%$ L) plants, which promoted an average loss $27 \%$ of TOC. When the proportion of non-leguminous plants in mixtures containing leguminous ones increased $(50 \% \mathrm{~L}$ and $50 \% \mathrm{NL}$ and $75 \% \mathrm{~L}$ and $25 \% \mathrm{NL}$ ), a lower drop was observed, being 15\% (Table 3). A decrease in OM content from soil cultivation, especially in the early years, has been reported in the literature (CUNHA et al., 2009a; CANELLAS et al., 2010). Moreover, the use of irrigation associated with high temperatures and the sandy texture of Typic Plinthustalf soil also may have contributed to the reduced $\mathrm{C}$ content. According to Guimarães et al. (2013) and Oliveira et al. (2016), irrigation can affect the quality and quantity of soil OM, favouring microbial activity in the soil. Also, the $\mathrm{C} / \mathrm{N}$ ratio (Table 2) of the deposited material may have contributed to the reduction of TOC. Organic materials added to soils with a low $\mathrm{C} / \mathrm{N}$ ratio tend to mineralise the $\mathrm{N}$ and immobilise the $\mathrm{C}$ in native soil, and their addition may result in depletion of OM content. The tillage exposes the previously protected OM from labile $\mathrm{OM}$ and therefore promotes microbial activity (STEVENSON, 1994). This decrease in TOC, however, can be reduced depending on the vegetation cover quality between rows used in cultivation. Thus, the treatment $75 \% \mathrm{~L}$ and $25 \% \mathrm{NL}$ led to minor losses of TOC (Table 3). 
T. J. F. CUNHA et al.

Table 3. Effects of treatments on total organic carbon and carbon fractions in fulvic acid, humic acid and humin.

\begin{tabular}{|c|c|c|c|c|}
\hline \multirow[t]{2}{*}{ Treatments } & TOC & $\mathbf{C}_{\mathrm{FA}}$ & $\mathrm{C}_{\mathrm{HA}}$ & $\mathrm{C}_{\mathrm{H}}$ \\
\hline & $\mathrm{g} \mathrm{kg}^{-1}$ & \multicolumn{3}{|c|}{ 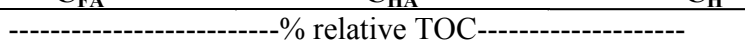 } \\
\hline $100 \% \mathrm{NL}$ & $0.65 \mathrm{~d}$ & $16.9 b$ & $9.2 \mathrm{c}$ & $26.2 \mathrm{e}$ \\
\hline $100 \% \mathrm{~L}$ & $0.66 \mathrm{~cd}$ & $15.2 \mathrm{~b}$ & $9.1 \mathrm{c}$ & $33.0 \mathrm{c}$ \\
\hline $75 \% \mathrm{~L}$ and $25 \% \mathrm{NL}$ & $0.84 \mathrm{ab}$ & $14.3 \mathrm{~b}$ & $9.5 \mathrm{bc}$ & $29.8 \mathrm{~d}$ \\
\hline $50 \% \mathrm{~L}$ and $50 \% \mathrm{NL}$ & $0.77 b c$ & $20.8 \mathrm{a}$ & $15.6 \mathrm{a}$ & $36.4 \mathrm{c}$ \\
\hline $25 \% \mathrm{~L}$ and $75 \% \mathrm{NL}$ & $0.77 b c$ & $20.8 \mathrm{a}$ & $14.3 \mathrm{a}$ & $55.8 \mathrm{a}$ \\
\hline SV & $0.90 \mathrm{a}$ & $13.3 b$ & $8.9 \mathrm{c}$ & $38.9 \mathrm{~b}$ \\
\hline
\end{tabular}

Means followed by the same letter in the column do not differ by Tukey test $(\mathrm{P} \leq 0,05)$. TOC - total organic carbon, $\mathrm{C}_{\mathrm{FA}}-$ carbon - fulvic acid, $\mathrm{C}_{\mathrm{HA}}$ - carbon - humic acid, $\mathrm{C}_{\mathrm{H}}$ - carbon - humin, NL - non-leguminous species, $\mathrm{L}$ - leguminous species, $\mathrm{SV}-$ spontaneous vegetation.

The type of vegetative cover between rows also modified the humified soil OM composition (Table 3). The treatments $50 \% \mathrm{~L}$ and $50 \% \mathrm{NL}$ as well as $25 \% \mathrm{~L}$ and $75 \%$ NL promoted increases in the order of $56 \%$ in the FA fraction and $75 \%$ and $60 \%$ in the HA fraction, respectively, in relation to the control (SV). These increases were significantly greater than those observed in the other treatments (100\% NL to $75 \% \mathrm{~L}$ and $25 \% \mathrm{NL}$ ) (Table 3), which varied in the order of $2-6 \% \mathrm{HA}$, or were similar to those found in soil samples from the control treatment (SV).

The most $\mathrm{C}$ portions of the HSs of the soil were found in the humic fraction $(26-56 \%)$, which is intimately associated with the mineral phase and therefore the insoluble alkaline extraction solution (Table 3). These results are in agreement with those of Canellas et al. (2010), indicating that the humic fraction typically predominates in tropical soils. The greatest amount of $\mathrm{H}$ in this study compared with other alkaline soluble fractions favours the structural stability of sandy textured soils, due to its greater recalcitrance compared to labile fractions, such as fulvic and humic acids. Moreover, most authors refer to this fraction as being chemically stable and subject to little variation in management (STEVENSON, 1994). However, in this study, there was variation in the humic fraction, probably due to the high $\mathrm{C}$ cycling in this environment, maximised by wetting and drying cycles caused by high air temperature and humidity resulting from irrigation. In addition, a 'priming effect' could be happening with the humic fraction $\mathrm{C}$ decomposition, which was previously present in the soil, due to the addition of plant mixtures; the addition could stimulate the activity of decomposing microorganisms, which, in addition to using the OM present in plant mixtures, also might have degraded the native soil OM (KUZYAKOV et al., 2000). This process is called the 'positive priming' effect (SILVA, 2005), which is characterized by intense microbial activity derived from plant mixtures added to an autochthonous soil (TRUU et al., 2009). Rather, there was large variation in the $\mathrm{C}$ content in the $\mathrm{H}$ fraction, and this variation is associated with different compositions of plant mixtures used in the vegetative cover between rows. Cultivation with a non-leguminous plant mixture $(100 \%$ NL) resulted in a $33 \%$ decrease in $\mathrm{C}$ in the $\mathrm{H}$ fraction, while the plant mixtures formed of only leguminous plants $(100 \% \mathrm{~L})$ increased $\mathrm{C}$ by $29 \%$ in this fraction (Table 3 ). The $25 \%$ nonleguminous plant mixture introduction $(75 \% \mathrm{~L}$ and $25 \% \mathrm{NL})$ decreased the $\mathrm{C}$ content in $\mathrm{H}(23 \%)$, whereas the plant mixtures consisting of $50 \% \mathrm{~L}$ and $50 \%$ NL had little influence on the $\mathrm{C}$ content in $\mathrm{H}$. With the $25 \% \mathrm{~L}$ and $75 \%$ NL plant mixture, there was an increase of approximately $44 \%$ in $\mathrm{C}_{\mathrm{H}}$ compared to the control (SV). These results demonstrate that leguminous species and nonleguminous species combinations may promote an increase in $\mathrm{C}$ content in HSs compared to the spontaneous vegetation (SV).

The $\mathrm{C}$ content contained in the three humic fractions $\left(\mathrm{C}_{\mathrm{H}}+\mathrm{C}_{\mathrm{HA}}+\mathrm{C}_{\mathrm{FA}}\right)$ represents more than half of the TOC, ranging from $52 \%$ in $\mathrm{T} 1$ to $91 \%$ in $\mathrm{T} 5$ (Table 4). The changes observed in the $\mathrm{C}$ content in different humic fractions are reflected in the relationships that express the soil OM quality (Table 4).

Table 4. Relationships among the humified soil fractions due to the vegetative cover type between rows.

\begin{tabular}{lcccc}
\hline \multirow{2}{*}{ Treatments } & $\mathbf{C}_{\mathbf{H A}}+\mathbf{C}_{\mathbf{F A}}+\mathbf{C}_{\mathbf{H}}$ & $\mathbf{C}_{\mathbf{H A}} / \mathbf{C}_{\mathbf{F A}}$ & $\mathbf{C}_{\mathbf{H}} /\left(\mathbf{C}_{\mathbf{H A}}+\mathbf{C}_{\mathbf{F A}}\right)$ & $\mathbf{C}_{\mathbf{H}}+\mathbf{C}_{\mathbf{H A}}+\mathbf{C}_{\mathbf{F A}} / \mathbf{C}_{\mathbf{T O C}}$ \\
\cline { 2 - 5 } & $\%$ of TOC & - & - & - \\
$100 \% \mathrm{NL}$ & $52.30 \mathrm{c}$ & $0.55 \mathrm{a}$ & $1.0 \mathrm{~d}$ & $80.46 \mathrm{~b}$ \\
$100 \% \mathrm{~L}$ & $57.24 \mathrm{c}$ & $0.60 \mathrm{a}$ & $1.3 \mathrm{c}$ & $86.72 \mathrm{~b}$ \\
$75 \% \mathrm{~L}$ and $25 \% \mathrm{NL}$ & $53.56 \mathrm{c}$ & $0.67 \mathrm{a}$ & $1.2 \mathrm{~d}$ & $63.76 \mathrm{c}$ \\
$50 \% \mathrm{~L}$ and $50 \% \mathrm{NL}$ & $72.71 \mathrm{~b}$ & $0.75 \mathrm{a}$ & $1.0 \mathrm{~d}$ & $94.43 \mathrm{~b}$ \\
$25 \% \mathrm{~L}$ and $75 \% \mathrm{NL}$ & $90.89 \mathrm{a}$ & $0.69 \mathrm{a}$ & $1.5 \mathrm{~b}$ & $118.04 \mathrm{a}$ \\
$\mathrm{SV}$ & $61.09 \mathrm{c}$ & $0.67 \mathrm{a}$ & $1.7 \mathrm{a}$ & $67.88 \mathrm{c}$ \\
\hline
\end{tabular}

Means followed by the same letter in the column do not differ by Tukey test $(\mathrm{P} \leq 0,05)$. $\mathrm{C}_{\mathrm{HA}}-$ carbon - humic acid, $\mathrm{C}_{\mathrm{FA}}-$ carbon - fulvic acid, $\mathrm{C}_{\mathrm{H}}$ - carbon - humin, TOC - total organic carbon, NL - non-leguminous species, L - leguminous species, $\mathrm{SV}$ - spontaneous vegetation. 
The $\mathrm{C}_{\mathrm{HA}} / \mathrm{C}_{\mathrm{FA}}$ ratio, which is an indicator of the degree of soluble OM condensation, shows the limited OM evolution, probably due to recent contributions from vegetative biomass by plant mixtures (LABRADOR MORENO, 1996). On the other hand, the low content of exchangeable bases also has facilitated a reduction in the intensity of the humification processes (condensation and biosynthesis) and, consequently, can be taken to obtain a low $\mathrm{C}_{\mathrm{HA}} / \mathrm{C}_{\mathrm{FA}}$ ratio (STEVENSON, 1994). Therefore, the results obtained indicate that the OM studied is characteristic of FA and a low humification degree. According to Orlov (1985), soil fertility is directly related to soil biological productivity, and larger and more diverse biological activity promotes the humification process and organic compound stabilisation in the $\mathrm{C}_{\mathrm{HA}}$ fraction. In this case, the greater FA presence can be associated with the soil quality and sandy loam (900 $\mathrm{g} \mathrm{kg}^{-1}$ of sand), which favours low nutrient levels that do not favour biological activity and evolution of soil OM processes.

The ratio $\mathrm{C}_{\mathrm{H}} /\left(\mathrm{C}_{\mathrm{HA}}+\mathrm{C}_{\mathrm{FA}}\right)$ is an indirect indicator of OM structural stability (CUNHA et al., $2009 \mathrm{~b}$ ), and it was verified that the $100 \% \mathrm{NL}$ as well as $50 \% \mathrm{~L}$ and $50 \% \mathrm{NL}$ treatments were those that exhibited the lowest values, suggesting that these plant mixtures provide greater HSs soluble base.

The ratio $\mathrm{C}_{\mathrm{H}}+\mathrm{C}_{\mathrm{HA}}+\mathrm{C}_{\mathrm{FA}}$ /TOC reports on the soil $\mathrm{OM}$ humification degree, and significant differences were observed among treatments, with the $25 \% \mathrm{~L}$ and $75 \% \mathrm{NL}$ treatment showing the largest values. This treatment promoted OM formation of a higher humification degree compared to the other treatments, suggesting that the input of organic wastes with a low $\mathrm{C} / \mathrm{N}$ ratio (Table 2) favours less-developed HS formation. Values ranged from 63.8-118.0, slightly out of the range typically found by Cunha et al. (2009a), whose values ranged from 65-92. It is likely that the leguminous species consortium and non-leguminous species decreased the TOC content (priming effect) and increased the relative proportion of HSs due to the loss of labile $\mathrm{C}$.

Humification can be characterised as a complex process based on biosynthesis and resynthesis of organic compounds that are incorporated into the soil (ZECH et al., 1997). These transformations include an oxidation reactions series, dehydration, hydrolysis, decarboxylation and condensation, which lead, as a rule, to a relative increase in N-containing HSs. The extent of these changes is influenced by intrinsic conditions, such as soil reaction and exchangeable base content; by organic waste quality and quantity; and by soil management (CANELLAS et al., 2007).

\section{Infrared spectroscopy of humic acids}

The spectra obtained and the absorption band located between 900 and 1,400 $\mathrm{cm}^{-1}$ were typical of HAs of soils (STEVENSON, 1994; SENESI et al., 2003; CUNHA et al., 2009b; VAZ Jr. et al., 2015). While not expected, insignificant changes were observed among the spectra of the HAs studied (Figure 1), which may be related to the short time period ( 3 years). The band around $1,080 \mathrm{~cm}^{-1}$ for the $\mathrm{C}-\mathrm{O}$ stretching of polysaccharides was well defined for the HAs of all treatments.

In the region below $1,800 \mathrm{~cm}^{-1}$, called the 'fingerprint', small differences were observed among the spectra. The similar characteristics but with different relative intensities were: (a) an intense and large absorption band centred between 3,300 and $3,470 \mathrm{~cm}^{-1}$, attributed to the stretching of phenolic $\mathrm{OH}$ groups (contributed by $\mathrm{OH}$ and an aliphatic amine); (b) one absorption band between 2,928 and $2,934 \mathrm{~cm}^{-1}$ and one less intense between 2,853 and $2,857 \mathrm{~cm}^{-1}$, attributed to the symmetric and asymmetric stretching of aliphatic $\mathrm{CH}$, respectively; (c) one absorption band between 1,246 and 1,250 cm -1 , attributed to the symmetric stretching of a carboxylate group; and (d) a strong absorption band in the region of 1,049-1,080 $\mathrm{cm}^{-1}$, attributed to $\mathrm{C}-\mathrm{O}$ stretching of polysaccharides and silicate impurities.

In general, the data obtained by infrared spectroscopy (DRIFT) suggest an aliphatic sample characteristic, a large amount of carboxylic groups and a large number of $\mathrm{N}$ groups in all the studied HAs - chain polypeptides, for example (SENESI et al., 2003).

The hydrophobicity indices (Table 5) varied from $0.28-0.41$. Analysis of these data reveals that the HA control treatment (SV) is distinct from those HA treatments that involved mixtures $(100 \%$ NL to $25 \% \mathrm{~L}$ and $75 \% \mathrm{NL}$ ), because HA control treatment is more hydrophobic. The more hydrophobicity observed for the HA of the control is probably related to more $\mathrm{OM}$ stability and selective preservation of the more recalcitrant $\mathrm{C}$ during the decomposition process of plant material $(\mathrm{ZECH}$ et al., 1997). As with other treatments, there was greater plant material amounts with a low $\mathrm{C} / \mathrm{N}$ ratio; this may have contributed to a lower degree of humification of these HA treatments compared to the control. 


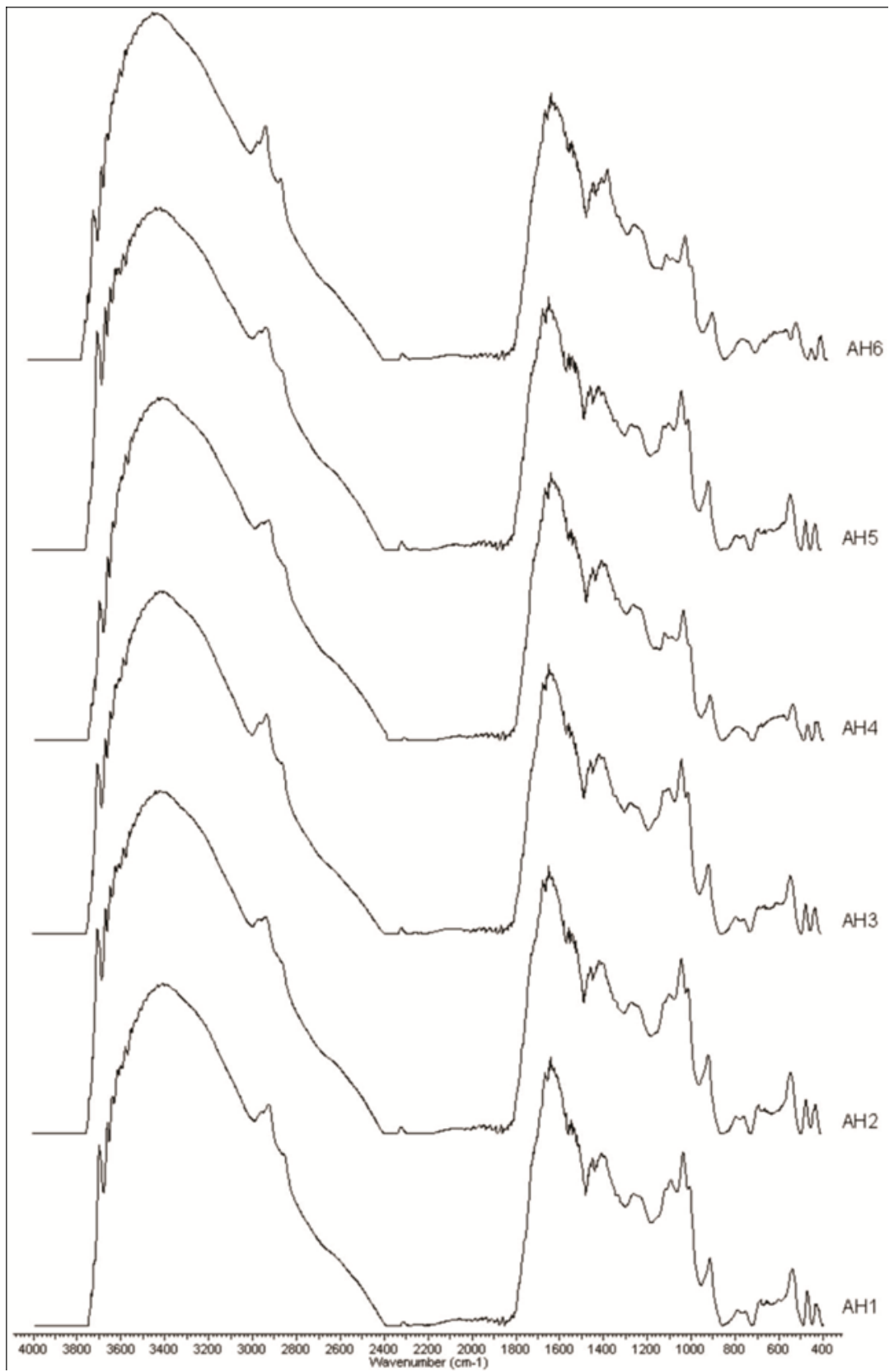

Figure 1. Infrared spectra of humic acids extracted from the 0-20-cm layer of a Typic Plinthustalf soil under different treatments (HA1 and HA6 correspond to the $100 \%$ NL to SV treatments, respectively).

Table 5. Hydrophobicity index (HI) of humic acids studied.

\begin{tabular}{lc}
\hline Treatments & HI \\
\hline $100 \% \mathrm{NL}$ & 0.28 \\
$100 \% \mathrm{~L}$ & 0.29 \\
$75 \% \mathrm{~L}$ and $25 \% \mathrm{NL}$ & 0.32 \\
$50 \% \mathrm{~L}$ and $50 \% \mathrm{NL}$ & 0.31 \\
$25 \% \mathrm{~L}$ and $75 \% \mathrm{NL}$ & 0.28 \\
SV & 0.41 \\
\hline
\end{tabular}

$\mathrm{NL}$ - non-leguminous species, $\mathrm{L}$ - leguminous species, $\mathrm{SV}$ - spontaneous vegetation. 


\section{CONCLUSIONS}

The plant mixtures cultivated between rows of the mango trees caused changes in the chemical composition of the soil OM.

The $25 \% \mathrm{~L}$ and $75 \%$ NL treatment was the best for minimising losses of soil TOC.

Most of the organic $\mathrm{C}$ was formed by HSs, with FA being the dominant fraction among the alkali soluble fractions.

HAs featuring large amounts of carboxyl and $\mathrm{N}$ groups reflect low levels of evolution and recalcitrance of this humic fraction.

\section{REFERENCES}

BENITES, V. M. Caracterização de solos e de substâncias húmicas em áreas de vegetação rupestre de altitude. 2002. 71 f. Tese (Doutorado em Solos e Nutrição de Plantas: Área de Concentração Manejo de Solo e Meio Ambiente) Universidade Federal de Viçosa, Viçosa, 2002.

BENITES, V. M. et al. Extração e fracionamento quantitativo de substâncias húmicas do solo: um procedimento simplificado de baixo custo. Rio de Janeiro: Embrapa Solos, 2003. 7 p. (Embrapa Solos. Comunicado Técnico, 16).

BRANCALIÃO, S. R.; MORAES, M. H. Alterações de alguns atributos físicos e das frações húmicas de um Nitossolo Vermelho na sucessão milheto-soja em sistema plantio direto. Revista Brasileira de Ciência do Solo, Viçosa, v. 32, n. 1, p. 393-404, 2008.

CANELLAS, L. P. et al. Chemical composition and bioactivity properties of size-fractions separated from a vermicompost humic acids. Chemosphere, Oxford, v. 78, n. 4, p. 457-466, 2010.

CANELLAS, L. P. et al. Estoque e qualidade da matéria orgânica de um solo cultivado com cana-deaçúcar por longo tempo. Revista Brasileira de Ciência do Solo, Viçosa, v. 31, n. 2, p. 331-340, 2007.

CARLETTI, P. et al. Structural characterization of humic-like substances with conventional and surface -enhanced spectroscopic techniques Journal of Molecular Structure, Amsterdam, v. 982, n. 1/3, p. 169-175, 2010.

CLASSEN, M. E. et al. Manual de métodos de análise de solos. 2. ed. Rio de Janeiro, RJ: EMBRAPA-CNPS, 1997. 212 p.
CUNHA, T. J. F. et al. Ácidos húmicos em solo fertirrigado no vale do São Francisco. Revista Brasileira de Ciência do Solo, Viçosa, v. 33, n. 6, p. 1583-1592, 2009a.

CUNHA, T. J. F. et al. Soil organic matter and fertility of anthropogenic dark earths (terra preta de índio) in the Brazilian Amazon basin. Revista Brasileira de Ciência do Solo, Viçosa, v. 33, n. 1, p. 85-93, 2009b.

USDA. Department of Agriculture. Keys to soil taxonomy. 11. ed. Washington, DC, 2010. 338 p.

FERRARI, E. et al. DRIFIT and HR MAS NMR characterization of humic substances from a soil treated with different organic and mineral fertilizers. Journal of Molecular Structure, Amsterdam, v. 998 , n. 1/3, p. 216-224, 2011.

FRANCIOSO, O. et al. Structural differences of chernozem soil humic acids SEC-PAGE fractions revealed by thermal (TG-DTA) and spectroscopic (DRIFT) analyses. Geoderma, Amsterdam, v. 152, n. 3/4, p. 264-268, 2009.

FREIXO, A. A. Propriedades espectrais da matéria orgânica leve-livre e leve intra-agregado de dois Latossolos sob plantio direto e preparo convencional. Revista Brasileira de Ciência do Solo, Viçosa, v. 26, n. 2, p. 445-453, 2002.

GUIMARÃES, R. M. L. et. al. Relating visual evaluation of soil structure to other physical properties in soils of contrasting texture and management. Soil and Tillage Research, Amsterdam, v. 127, n. 1, p. 92-99, 2013.

KONONOVA, M. M. Matéria orgânica del suelo: su natureza, propriedades y métodos de investigacion. Barcelona: Oikos-Tau, 1982. 365 p.

KUZYAKOV, Y. et al. Review of mechanisms and quantification of priming effects. Soil Biology and Biochemistry, Oxford, v. 32, p. 11/12, p. 14851498, 2000.

LABRADOR MORENO, J. La matéria organica en los agrosistemas. Madrid: Ministerio de Agricultura, Pesca y Alimentación, 1996. 176 p.

LIEFELD, J. Application of diffuse reflectance FTIR spectroscopy and partial least-squares regression to predict NMR properties of soil organic matter. European Journal of Soil Science, Oxford, v. 57, n. 6, p. 846-857, 2006.

$\mathrm{MAO}$, J. et al. Influence of animal manure application on the chemical tructures of soil organic matter as investigated by advanced solid-state NMR 
and FT-IR spectroscopy. Geoderma, Amsterdam, v. 146, n.1/2, p. 353-362, 2008.

NOVOTNY, E. H. Estudos espectroscópicos e cromatográficos de substâncias húmicas de solos sob diferentes sistemas de preparo. 2002. 215 p. Tese (Doutorado em Ciências: Área de Concentração em Físico Química) - Universidade de São Paulo, São Carlos, 2002.

OLIVEIRA, S. P. et al. Conversion of forest into irrigated pasture. I. Changes in the chemical and biological properties of the soil. Catena, Destedt, v. 137 , n. 1, p. 508-516, 2016

OLK, D. C. et al. Decrease in humification of organic matter with intensified lowland rice cropping a wet chemical and spectroscopic investigation. Soil Science Society of America Journal, Madison, v. 64, n. 4, p. 1337-1347, 2000.

ORLOV, D. S. Organic substances of russian soils. European Journal of Soil Science, Oxford, v, 31, n. 9, p. 946-953, 1998.

ORLOV, R. Humic acids of soils. Washington, DC: USDA, 1985. 378 p.

PICCOLO, A. Carbon sequestration in agricultural soils. Heidleberg, Germany: SPRINGER VERLAG, 2012. 306 p.

SALCEDO, I. H.; SAMPAIO, E. V. S. B. Matéria orgânica do solo no Bioma Caatinga. In: SANTOS, G.; CAMARGO, F. (Eds.). Fundamentos da matéria orgânica do solo: ecossistemas tropicais e subtropicais. 2. ed. Porto Alegre: Metrópole, 2008. p. 419-441.

SCHNITZER, M. Organic matter characterization. In: PAGE, A. L. et al. (Ed.). Methods of soil analysis: chemical and microbiological properties. 2 . ed. Madison: SSSA, 1982. v. 2, cap. 30, p. 581-594. (SSSA. Agronomy, 9).

SENESI, N. et al. Humic acids in the first generation of eurosoils. Geoderma, Amsterdam, v. 116, n. 3/4, p. 325-344, 2003.

SILVA, F. A. M. Qualidade de compostos orgânicos produzidos com resíduos do processamento de plantas medicinais. $2005.102 \mathrm{f}$. Tese (Doutorado em Agronomia: Área de Concentração em Energia da Agricultura) Universidade Estadual Paulista Júlio de Mesquita Filho, Botucatu, 2005.

SILVA, F. C. da. Manual de análises químicas de solos, plantas e fertilizantes. Brasília, DF: Embrapa
Comunicação para Transferência de Tecnologia, 1999. 370 p.

SIMONETTI, G. et al. Characterization of humic carbon in soil aggregates in a long-term experiment with manure and mineral fertilization. Soil Science Society of America Journal, Madison, v. 76, n. 3, p. 880-890, 2012

SIMPSON, A. J. Determining the molecular weight, aggregation, structures and interactions of natural organic matter using diffusion ordered spectroscopy. Magnetic Resonance in Chemistry, Chichester, v. 40, n. 13, p. S72-S82, 2002.

STEVENSON, F. J. Humus chemistry: genesis, composition, reactions. 2. ed. New York: John Willey, 1994. 496 p.

SWIFT, R. S. Organic matter characterization. In: SPARKS, D. L et al. (Eds.). Methods of soil analysis: chemical methods. Madison: SSSA, 1996. v. 3, p. 1011-1020. (SSSA. Book Series, 5).

TRUU, M. et al. Microbial biomass, activity and community composition in constructed wetlands. Science of the Total Environment, Amsterdam, v. 407, n. 13 , p. $3958-3971.2009$.

VAZ JUNIOR, S. et al. Study of molecular interactions between humic acid from Brazilian soil and the antibiotic oxytetracycline. Environmental Technology \& Innovation, Amsterdam, v. 4, n., p. 260-267, 2015.

YEOMANS, J. C.; BREMNER, J. M. A rapid and precise method for routine determination of organic carbon in soil. Communications in Soil Science and Plant Analysis, New York, v. 19, n. 13, p. 1467 $-1476,1988$.

ZECH, W. et al. Factors controlling humification and mineralization of soil organic matter in the tropics. Geoderma, Amsterdam, v. 79, n. 1/4, p. 117 $-161,1997$. 